\title{
CD45 Deficiency Drives Amyloid- $\beta$ Peptide Oligomers and Neuronal Loss in Alzheimer's Disease Mice
}

\author{
Yuyan Zhu, ${ }^{1,2 *}$ Huayan Hou, ${ }^{1 *}$ Kavon Rezai-Zadeh, ${ }^{6}$ Brian Giunta, ${ }^{1,2}$ Amanda Ruscin, ${ }^{1,2}$ Carmelina Gemma, ${ }^{3}$ \\ JingJi Jin, ${ }^{1,2}$ Natasa Dragicevic, ${ }^{4}$ Patrick Bradshaw, ${ }^{4}$ Suhail Rasool, ${ }^{8}$ Charles G. Glabe, ${ }^{8}$ Jared Ehrhart, ${ }^{1,2}$ \\ Paula Bickford, ${ }^{3,5}$ Takashi Mori, ${ }^{9}$ Demian Obregon, ${ }^{1,2}$ Terrence Town, ${ }^{6,7,10}$ and Jun Tan ${ }^{1,2,5}$ \\ ${ }^{1}$ Rashid Laboratory for Developmental Neurobiology, Silver Child Development Center and ${ }^{2}$ Neuroimmunology Laboratory, Department of Psychiatry and \\ Behavioral Medicine, College of Medicine, University of South Florida, Tampa, Florida 33613, 32Departments of Neurosurgery and Brain Repair, \\ ${ }^{4}$ Department of Biology, College of Arts and Science, University of South Florida, Tampa, Florida 33613, 5James A. Haley Veterans Affairs Medical Center, \\ Tampa, Florida 33612, ${ }^{6}$ Department of Biomedical Sciences, Research Divisions of Neurobiology and Immunology, Regenerative Medicine Institute and \\ ${ }^{7}$ Department of Neurosurgery, Maxine Dunitz Neurosurgical Institute, Cedars-Sinai Medical Center, Los Angeles, California 90048, ${ }^{8}$ Department of

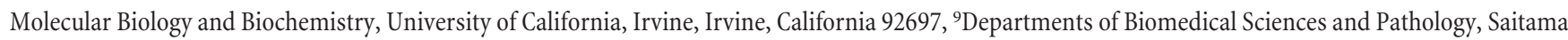 \\ Medical Center/Saitama Medical University, Kawagoe, Saitama 350-8550, Japan, and ${ }^{10}$ Department of Medicine, David Geffen School of Medicine, \\ University of California, Los Angeles, Los Angeles, California 90048
}

Converging lines of evidence indicate dysregulation of the key immunoregulatory molecule CD45 (also known as leukocyte common antigen) in Alzheimer's disease (AD). We report that transgenic mice overproducing amyloid- $\beta$ peptide (A $\beta)$ but deficient in CD45 (PSAPP/CD $45^{-1-}$ mice) faithfully recapitulate AD neuropathology. Specifically, we find increased abundance of cerebral intracellular and extracellular soluble oligomeric and insoluble $\mathrm{A} \beta$, decreased plasma soluble $\mathrm{A} \beta$, increased abundance of microglial neurotoxic cytokines tumor necrosis factor- $\alpha$ and interleukin-1 $\beta$, and neuronal loss in PSAPP/CD45 ${ }^{-1-}$ mice compared with CD45-sufficient PSAPP littermates (bearing mutant human amyloid precursor protein and mutant human presenilin-1 transgenes). After CD45 ablation, in vitro and in vivo studies demonstrate an anti-A $\beta$ phagocytic but proinflammatory microglial phenotype. This form of microglial activation occurs with elevated $\mathrm{A} \beta$ oligomers and neural injury and loss as determined by decreased ratio of anti-apoptotic Bcl-xL to proapoptotic Bax, increased activated caspase-3, mitochondrial dysfunction, and loss of cortical neurons in PSAPP/CD45 ${ }^{-1-}$ mice. These data show that deficiency in CD45 activity leads to brain accumulation of neurotoxic $\mathrm{A} \beta$ oligomers and validate $\mathrm{CD} 45$-mediated microglial clearance of oligomeric $\mathrm{A} \beta$ as a novel $\mathrm{AD}$ therapeutic target.

\section{Introduction}

Deposition of amyloid- $\beta$ peptide $(\mathrm{A} \beta)$ as $\beta$-amyloid plaques is a defining pathological hallmark of Alzheimer's disease (AD) and occurs with increased abundance of soluble $A \beta$ and activation of microglia-mediated inflammatory responses (Sedgwick et al., 1991). However, reactive microglia ultimately fail to clear $A \beta$ in brains of $\mathrm{AD}$ patients and in mouse models of the disease

Received June 24, 2010; revised Nov. 2, 2010; accepted Nov. 4, 2010.

This work was supported by the National Institutes of Health (NIH)/National Institute on Aging (NIA) Grants AG04418/Project-2 (J.T.) and R01AG032432 (J.T.) and NIH/National Institute of Neurological Disorders and Stroke Grant R01NS048335 (J.T.). B.G. is supported by NIH/National Institute of Mental Health Clinical Scientist Award 1 K08 MH082642-01A1. T.T. is supported by NIH/NIA "Pathway to Independence" Awards 5R00AG029726-03, 5R00AG029726-04, and 3R00AG029726-04S1, is the recipient of Alzheimer's Association Zenith Fellows Award ZEN-10-174663, and is the inaugural holder of the Ben Winters Endowed Chair in Regenerative Medicine. We thank David Morgan (University of South Florida) for helpful advice. Mosaic images were taken by the Analytic Microscopy Core Facility at H. Lee Moffitt Cancer Center.

*Y.Z. and H.H. contributed equally to this work.

Correspondence should be addressed to either of the following: Dr. Jun Tan, Rashid Laboratory for Developmental Neurobiology, Silver Child Development Center, Department of Psychiatry and Behavioral Medicine, College of Medicine, University of South Florida, 3515 East Fletcher Avenue, Tampa, FL 33613, E-mail: jtan@hsc.usf.edu; or Dr. Terrence Town, Regenerative Medicine Institute, Department of Biomedical Sciences, Cedars-Sinai Medical Center, 8700 Beverly Boulevard, Steven Spielberg Building, Room 361, Los Angeles, CA 90048, E-mail: townt@cshs.org. DOI:10.1523/JNEUROSCI.3268-10.2011

Copyright $\odot 2011$ the authors $\quad 0270-6474 / 11 / 311355-11 \$ 15.00 / 0$
(McGeer et al., 1987; Benzing et al., 1999). It has even been suggested that chronic microglial immune responses contribute to $\mathrm{AD}$ pathogenesis by promoting $\mathrm{A} \beta$ plaque formation (Frackowiak et al., 1992; Wisniewski and Frackowiak, 1998; Townsend et al., 2005), but the molecular mechanisms underlying this deleterious response have remained elusive.

CD45 (also known as leukocyte common antigen), the most abundant transmembrane protein tyrosine phosphatase, is expressed on all nucleated hematopoietic cells and plays an important role in regulating immune responses (Thomas and Brown, 1999; Penninger et al., 2001). In the periphery, CD45 promotes antigen-specific B- and T-cell responses by dephosphorylating Src-family kinases (Thomas and Brown, 1999; Penninger et al., 2001). CD45 plays additional roles in regulating selectin expression (Stibenz et al., 1996; Wroblewski and Hamann, 1997) and integrin function (Roach et al., 1997; Shenoi et al., 1999). CD45 has also been shown to negatively regulate cytokine receptormediated signaling via Janus associated kinases (Irie-Sasaki et al., 2001), revealing yet another role of CD45 in dampening overly exuberant immune responses.

Resting microglia constitutively express CD45 in vitro, which is further inducible at the cell surface during activation (Sedgwick 
et al., 1991; Carson et al., 1998). Importantly, microglia in the frontal cortex and hippocampus of normal aging individuals express CD45, and expression abundance is markedly increased in close vicinity of $\beta$-amyloid plaques in $\mathrm{AD}$ patient brains (Masliah et al., 1991) and in transgenic mouse models of the disease (Wilcock et al., 2001; Maier et al., 2008). Stimulation of microglial CD45 opposes CD40 ligand (CD40L)-induced activation of the Src-family kinases Lck and Lyn, which are key transducers of proinflammatory innate immune responses (Tan et al., 2000a). Cotreatment of microglia with CD40L and agonistic CD45 antibody abrogates microglial tumor necrosis factor- $\alpha$ (TNF- $\alpha$ ) production via inhibiting p44/42 mitogen-activated protein kinase (MAPK) activity, a downstream signaling event resulting from Src-family kinase activation (Tan et al., 2000a,b). Thus, stimulation of the CD45 signaling pathway suppresses proinflammatory microgliosis that is etiologically implicated in neurodegenerative disorders, including AD (Akiyama et al., 2000; Tan et al., 2000b; Penninger et al., 2001).

To elucidate the role of CD45 in AD-like pathology, we took a genetic approach to cross doubly transgenic PSAPP mice [bearing mutant human amyloid precursor protein (APP) and mutant human presenilin-1 (PS1) transgenes], which develop accelerated cerebral amyloidosis (Jankowsky et al., 2001), with animals deficient in CD45 (Benatar et al., 1996). We then examined ADlike pathology in bigenic mice as detailed to follow.

\section{Materials and Methods}

Mice. All mice were housed and maintained in the College of Medicine Animal Facility at the University of South Florida (USF), and all experiments were conducted in compliance with protocols approved by the USF Institutional Animal Care and Use Committee. Double transgenic "Swedish" APPK595N/M596L (APPswe) + PS1 $1_{\Delta \mathrm{E} 9}$ B6C3-Tg 85Dbo/J

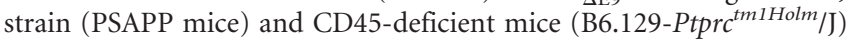
were purchased from The Jackson Laboratory. PSAPP mice were maintained as heterozygotes by crossing transgenic mice to wild-type B6C3F1/J mice as described in the original report (Jankowsky et al., 2001). We interbred first filial offspring resulting from crossing heterozygous PSAPP mice with homozygous CD45-deficient mice and analyzed four groups of mice at 4 and 8 months of age: nontransgenic/CD45 wild-type (wild-type), PSAPP/CD45 wild-type (PSAPP), nontransgenic/ $C D 45^{-/-}\left(C D 45^{-/-}\right)$, and PSAPP/CD $45^{-/-}$offspring. Animals were screened for PSAPP and CD45 genotypes by PCR from genomic DNA. CD45 genotype was further confirmed by flow cytometry. Because sex differences can impact A $\beta$ deposition (Jankowsky et al., 2001), we used only females in our analyses.

Protein extraction. For specific extraction of extracellular versus intracellular proteins, hemibrains were harvested and placed in $500 \mu \mathrm{l}$ of solution containing $50 \mathrm{~mm}$ Tris- $\mathrm{HCl}, \mathrm{pH}$ 7.6, 0.01\% NP-40, $150 \mathrm{~mm}$ $\mathrm{NaCl}, 2$ mm EDTA, 0.1\% SDS, 1 mm phenylmethylsulfonyl fluoride, and protease inhibitor cocktail (Sigma) as described (Lesné et al., 2006). Soluble, extracellular proteins were collected from mechanically homogenized lysates after centrifugation for $5 \mathrm{~min}$ at $3000 \mathrm{rpm}$. Cytoplasmic proteins were extracted from cell pellets mechanically dissociated with a micropipettor in $500 \mu \mathrm{l}$ of TNT buffer ( $50 \mathrm{~mm}$ Tris-HCl, pH 7.6, $150 \mathrm{~mm}$ $\mathrm{NaCl}$, and $0.1 \%$ Triton X-100) after centrifugation for 90 min at 13,000 $\mathrm{rpm}$. Insoluble material was incubated with $20 \mu \mathrm{l}$ of $70 \%$ formic acid, mechanically dissociated with a micropipette, gently agitated for $1 \mathrm{~h}$, and buffered with $380 \mu \mathrm{l}$ of $1 \mathrm{M}$ Tris- $\mathrm{HCl}, \mathrm{pH}$ 8.0. Samples were centrifuged for $90 \mathrm{~min}$ at 13,000 rpm, and supernatants were collected for analysis.

For total protein extraction, brains were removed and hemibrains were snap-frozen on dry ice and stored at $-80^{\circ} \mathrm{C}$. Samples were subsequently homogenized in immunoprecipitation assay buffer containing the following: $150 \mathrm{~mm} \mathrm{NaCl}, 50 \mathrm{~mm}$ Tris, $\mathrm{pH}$ 7.4, 0.5\% deoxycholic acid, $0.1 \%$ SDS, $1 \%$ Triton X-100, 2.5 mм EDTA, and protease inhibitor cocktail. Protein concentration was measured in the supernatant by BCA Protein Assay (Pierce).
Western blotting. Following the sample preparation as described above, an aliquot corresponding to $40 \mu \mathrm{g}$ of total protein was electrophoretically separated using 10\% Tris-SDS gels or 10-20\% Tris-tricine gels (Bio$\mathrm{Rad}$ ) and transferred to polyvinylidene fluoride membranes (Bio-Rad). As a positive control, $A \beta$ oligomers were prepared from synthetic human $\mathrm{A} \beta_{1-42}$ according to published methods (Walsh et al., 2000; Lesné et al., 2006). Membranes were blocked for $1 \mathrm{~h}$ at room temperature in Trisbuffered saline (TBS) (containing $0.1 \%$ Tween 20 with $5 \%$ nonfat dry milk) and were then incubated with primary antibodies including mouse monoclonal neuronal-specific nuclear protein (NeuN) (1:1000; Millipore Corporation), rabbit polyclonal Bcl-xL or Bax (1:1000; Cell Signaling Technology), mouse monoclonal 6E10 (1:2000; Covance), or mouse monoclonal $\beta$-actin (1:4000; Sigma). Afterward, membranes were immunoblotted with anti-mouse (1:2000; Cell Signaling Technology) or anti-rabbit (1:10,000; Pierce) IgG secondary antibodies conjugated with horseradish peroxidase. Proteins were detected with Super Signal West Femto Maximum Sensitivity Substrate (Pierce) and BIOMAX-MR Film (Thermo Fisher Scientific).

ELISA. For TNF- $\alpha$ and interleukin- $1 \beta$ (IL- $1 \beta$ ) ELISAs, total proteins were extracted from mouse brain homogenates as described above. We then collected supernatants and diluted them at 1:4 in lysis buffer for detection of TNF- $\alpha$ (R \& D Systems) or IL- $1 \beta$ (eBioscience), in accordance with the instructions of the manufacturer. Total protein concentrations were determined for each brain sample before quantification of cytokines by ELISA to allow for sample normalization. For A $\beta$ ELISA, separate extracts of extracellular and intracellular proteins were prepared from mouse brain homogenates as described above. Quantification of total $\mathrm{A} \beta$ species (including $\mathrm{A} \beta_{1-40,42}$ ) was performed according to published methods (Rezai-Zadeh et al., 2005). Total soluble $A \beta$ species in blood plasma and extracellular/intracellular $A \beta$ in brain homogenates were detected at 1:4 and 1:20 dilutions, respectively. Detergent-insoluble total $\mathrm{A} \beta$ species were detected in brain by extracting pellets in $5 \mathrm{~m}$ guanidine $\mathrm{HCl}$ buffer, followed by a 1:20 dilution in lysis buffer. $\mathrm{A} \beta_{1-40,42}$ was quantified in all samples using $\mathrm{A} \beta_{1-40,42}$ ELISA kits (IBL-America) in accordance with the instructions of the manufacturer, except that standards included $0.25 \mathrm{M}$ guanidine $\mathrm{HCl}$ buffer in some cases.

Tissue preparation. Mice were killed under isoflurane anesthesia, and $0.5 \mathrm{ml}$ of blood was collected from the heart. Plasma was then separated and stored at $-80^{\circ} \mathrm{C}$ for later analysis of $\mathrm{A} \beta$ levels. Animals were then transcardially perfused with ice-cold PBS. Brains were rapidly isolated and the right hemisphere was snap-frozen on dry ice and stored at $-80^{\circ} \mathrm{C}$ before protein extraction. The left hemisphere was placed in $4 \%$ paraformaldehyde (PFA) in $0.1 \mathrm{M}$ PBS overnight and then transferred to a graded series of sucrose solutions $\left(10,20\right.$, and $30 \%$, each at $4^{\circ} \mathrm{C}$ overnight) for cryoprotection. Sequential 25 or $40 \mu \mathrm{m}$ frozen coronal sections were cut using a sliding microtome. Free-floating sections were then stored at $4^{\circ} \mathrm{C}$ in 24-well plates containing PBS with $100 \mathrm{~mm}$ of sodium azide.

Histochemistry. Brain sections were incubated for $5 \mathrm{~min}$ in a $1 \%$ thioflavin S (ThioS) (Sigma) solution dissolved in distilled water containing $70 \%$ ethanol. We then rinsed tissue sections twice with distilled water and mounted them with fluorescence mounting medium containing $4^{\prime}, 6^{\prime}$ diamidino-2-phenylindole (DAPI) (Vector Laboratories). Nissl staining was performed to assay neuronal morphology. Briefly, free-floating frozen sections were mounted on slides and air dried before overnight incubation with a 1:1 solution of alcohol and chloroform. Afterward, sections were rehydrated through a graded series of alcohols and distilled water and stained with $0.1 \%$ cresyl violet solution for 5-10 min. Slides were then rinsed in distilled water and dehydrated in $95 \%$ ethanol. After dehydration, slides were mounted with mounting medium and visualized in bright field. Congo red staining was performed as described previously (Shankar et al., 2008).

Immunohistochemistry. Brain sections were stained with rat antimouse CD11b (1:1000; Serotec), fluorescein isothiocyanate (FITC)conjugated hamster anti-mouse CD40 (1:100; BD Biosciences Pharmingen), rabbit anti-mouse ionized calcium binding adaptor molecule 1 (Iba1) (1:1000; Wako Pure Chemicals), hamster anti-mouse CD11c (1:50; Pierce), rat anti-mouse chemokine receptor Ccr2 (1:100; Novus Biologicals), mouse anti-human $\mathrm{A} \beta$ (clones $4 \mathrm{G} 8$ or $6 \mathrm{E} 10$; 1:500; Covance), or mouse anti-NeuN (1:3000; Millipore). We incubated brain 
sections with species-specific Alexa Fluor 488- and 594-conjugated secondary antibodies (Invitrogen) for $1 \mathrm{~h}$ at room temperature, followed by staining with the VECTASTAIN Elite ABC kit (Vector Laboratories) coupled with 3,3'-diaminobenzidine substrate. Sections were analyzed in independent channels with an Olympus FV1000 laser scanning confocal microscope equipped with Fluoview SV1000 imaging software.

Quantification of $A \beta$ deposits. We quantified $\mathrm{A} \beta$ deposits by immunofluorescence using six $25 \mu \mathrm{m}$ free-floating sections spaced $200 \mu \mathrm{m}$ apart through each anatomic region of interest (hippocampus and cerebral cortex) as described previously (Tan et al., 2002; Town et al., 2008). Brain sections were immunostained with rabbit polyclonal oligomer/conformational (OC) A $\beta$ antibody (Kayed et al., 2007) (provided by S.R. and C.G.G.), using Alexa Fluor 488-conjugated goat anti-rabbit secondary antibody (Invitrogen). Amyloid burden was determined at $20 \times$ magnification by quantitative image analysis using an automated Zeiss Observer Z1 inverted microscope with an attached Axiocam MRm CCD camera and Axiovision software version 4.6 (Carl Zeiss). For measurement of microglial distances from $A \beta$ deposits, brain sections were double labeled with Ibal antibody and Congo red, and the distance of microglia from the center of the nearest $\mathrm{A} \beta$ plaque was blindly measured in 8-month-old PSAPP/CD45 or PSAPP/CD $45^{-1-}$ mice using SimplePCI software (Hamamatsu Photonics). Quantitative image analysis was performed by a single examiner (T.M.) blinded to sample identities. Data are reported as percentage of positive pixels divided by total pixels captured for each region of interest.

Murine primary cell culture. Murine primary cultured microglia were isolated from mouse cerebral cortices and grown in complete RPMI 1640 medium according to previously described methods (Zhu et al., 2008). Briefly, cerebral cortices from newborn mice (1-2 d old) were isolated under sterile conditions and kept at $4^{\circ} \mathrm{C}$ before mechanical dissociation. Cells were grown in RPMI 1640 medium supplemented with 5\% heatinactivated FCS, $2 \mathrm{~mm}$ glutamine, $100 \mathrm{U} / \mathrm{ml}$ penicillin, $100 \mu \mathrm{g} / \mathrm{ml}$ streptomycin, and 50 nм 2-mercaptoethanol. Primary cultures were kept for $14 \mathrm{~d}$ so that only glial cells remained. Astrocytes were separated from microglial cultures using a mild trypsinization protocol as described (Saura et al., 2003). More than $98 \%$ of these glial cells stained positive for Mac-1 (Roche Diagnostics) by flow cytometry.

Microglial phagocytosis assay. Primary mouse microglia were seeded at $1 \times 10^{5}$ cells per well ( $n=6$ for each condition) in 24-well tissue culture plates containing $0.5 \mathrm{ml}$ of complete RPMI 1640 medium for fluorometric analysis of $\mathrm{A} \beta$. These cells were treated for $2 \mathrm{~h}$ with "aged" $\mathrm{A} \beta_{1-42}[500$ nM; preaggregated for $24 \mathrm{~h}$ at $37^{\circ} \mathrm{C}$ in complete medium as described by Chung et al. (1999) and conjugated with FITC (FITC-A $\beta_{1-42}$ ) (Bachem Americas)]. Microglial cells were then cotreated with agonistic CD45 antibody or isotype control $\operatorname{IgG}(2.5 \mu \mathrm{g} / \mathrm{ml})$ for $2 \mathrm{~h}$ in the presence of FITC-A $\beta_{1-42}$. Cells were then rinsed three times in $\mathrm{A} \beta$-free complete medium, and the medium was exchanged with fresh $\mathrm{A} \beta$-free complete medium for 10 min to allow for removal of non-incorporated $A \beta$ and to promote concentration of $A \beta$ into phagosomes. Extracellular (in cell culture media) and cell-associated (in cell lysates) FITC-A $\beta$ were quantified using an MSF SpectraMax spectrophotometer (Molecular Devices) with an emission wavelength of $538 \mathrm{~nm}$ and an excitation wavelength of $485 \mathrm{~nm}$. A standard curve from 0 to $600 \mathrm{~nm}$ FITC-A $\beta$ was generated for each plate. Total cellular proteins were quantified by BCA Protein Assay. The mean fluorescence values for each sample at $37^{\circ} \mathrm{C}$ and $4^{\circ} \mathrm{C}$ at the $2 \mathrm{~h}$ time point were determined by fluorometric analysis. Relative fold change values were calculated as follows: mean fluorescence value for each sample at $37^{\circ} \mathrm{C} /$ mean fluorescence value for each sample at $4^{\circ} \mathrm{C}$. Considering nonspecific adherence of $A \beta$ to the plastic surface of culture plates, an additional control without cells was performed in parallel for each experiment above. An incubation time of $<4 \mathrm{~h}$ did not change the amount of $\mathrm{A} \beta$ peptide detected in the supernatant, consistent with a previous report (Mitrasinovic and Murphy, 2002). To determine whether cell death influenced $\mathrm{A} \beta$ uptake in the various treatment groups, we performed lactate dehydrogenase release assays but did not detect significant $(p>0.05)$ cell death over the $3 \mathrm{~h}$ experimental timeframe in any of the treatment groups (data not shown).

Confocal microscopy. "Aged" FITC-A $\beta_{1-42}$ was prepared according to methods described above. Microglial cells were cultured at $1 \times 10^{5}$ cells per well in 24-well tissue culture plates with glass inserts. These cells were treated for $2 \mathrm{~h}$ with aged FITC-A $\beta_{1-42}$. Separate groups of microglial cells were incubated in parallel at $4^{\circ} \mathrm{C}$ (control). After treatment, cells were washed five times with ice-cold PBS to remove non-incorporated FITC$\mathrm{A} \beta_{1-42}$ and fixed for $10 \mathrm{~min}$ at $4^{\circ} \mathrm{C}$ in $4 \% \mathrm{PFA}$, followed by three rinses in PBS. Finally, sections were mounted with fluorescence mounting media containing DAPI (ProLong Gold; Invitrogen) and viewed with a Leica SP5 confocal microscope (Leica Microsystems). Excitation wavelengths of $488 \mathrm{~nm}$ (to reveal FITC-A $\beta_{1-42}$ ) and $405 \mathrm{~nm}$ (for DAPIcounterstained nuclei) were used. Images were captured and analyzed using LAS AF software version 1.6.0 (Leica Microsystems). Normarski optic (differential interference contrast) images were captured in wide field to accompany each confocal image.

Stereological analysis. We stained $40 \mu \mathrm{m}$ free-floating serial brain sections in plastic multiwell carriers with nylon net bottoms using NeuN antibody as described above. To prepare for unbiased stereologic estimation of neuronal counts, an initial tissue section was randomly selected at one anatomic border of the brain region to be examined. Thereafter, every sixth section throughout the anatomic region of interest was used for each counting series. NeuN-positive cells were examined with a Nikon Eclipse 600 microscope and quantified using Stereo Investigator software, version 6 (MicroBrightField). Cells were counted in the entorhinal cortex using the optical fractionator method of unbiased stereologic cell counting (West et al., 1991). Our sampling method was optimized to count at least 250 cells per animal with error coefficients of $<0.07$. Each counting frame $(50 \times 50 \mu \mathrm{m})$ was placed at an intersection of the lines forming a virtual grid $(200 \times 200 \mu \mathrm{m})$, which was randomly generated and placed by the software within the outlined structure.

Statistical analysis. All data were normally distributed; therefore, in instances of single mean comparisons, Levene's test for equality of the variance followed by $t$ test for independent samples was used to assess significance. In instances of multiple mean comparisons, ANOVA was used, followed by post hoc comparison using Bonferroni's method. $\alpha$ levels were set at 0.05 for all analyses. The Statistical Package for the Social Sciences release 10.0.5 (SPSS) was used for all data analysis.

\section{Results \\ Cerebral amyloidosis is increased in aged PSAPP mice deficient in CD45}

Brain $\mathrm{A} \beta$ deposition is a pathognomonic feature of $\mathrm{AD}$ (Selkoe, 2001 ), and oligomeric $A \beta$ species are thought to be a driving force in AD-type neurodegeneration (Klyubin et al., 2005; Walsh et al., 2005; Shankar et al., 2008). The double-transgenic PSAPP mouse (Jankowsky et al., 2001) is a widely used model of cerebral amyloidosis, and we bred PSAPP mice with animals deficient in CD45 and killed offspring at either 4 or 8 months of age to evaluate changes in $\mathrm{AD}$-like pathology. We reacted mouse brain sections with OC antibody directed against oligomeric/conformational A $\beta$ species (Kayed et al., 2007; Glabe, 2008) and counterstained cell nuclei with DAPI (Fig. 1a) (supplemental Fig. $1 a$, available at www.jneurosci.org as supplemental material) and also stained for fibrillar $\mathrm{A} \beta$ with ThioS (Fig. 1b). A $\beta$ burden was calculated for OC or ThioS stains (within cingulate cortex, hippocampus, and entorhinal cortex) by quantitative image analysis. Data are represented as mean $\pm \mathrm{SD}$ with $n=8$ females per group at 4 or 8 months of age. Quantitative image analysis revealed significantly $\left.{ }^{* *} p<0.01\right)$ increased OC reactivity at 4 months of age and Thios burden at 8 months of age by $56-60 \%$ when comparing PSAPP $/ C D 45^{-1-}$ to PSAPP/CD45 littermates. By 8 months of age, $P S A P P / C D 45^{-1-}$ animals had only modest elevation in OC immunoreactivity (supplemental Fig. $1 b$, available at www. jneurosci.org as supplemental material), suggesting that CD45 deficiency accelerates cerebral amyloidosis as opposed to having a cumulative effect on $\mathrm{A} \beta$ pathology. As expected, altered cerebral $\mathrm{A} \beta$ abundance in $P S A P P / C D 45^{-/-}$versus PSAPP/CD45 mice was not 


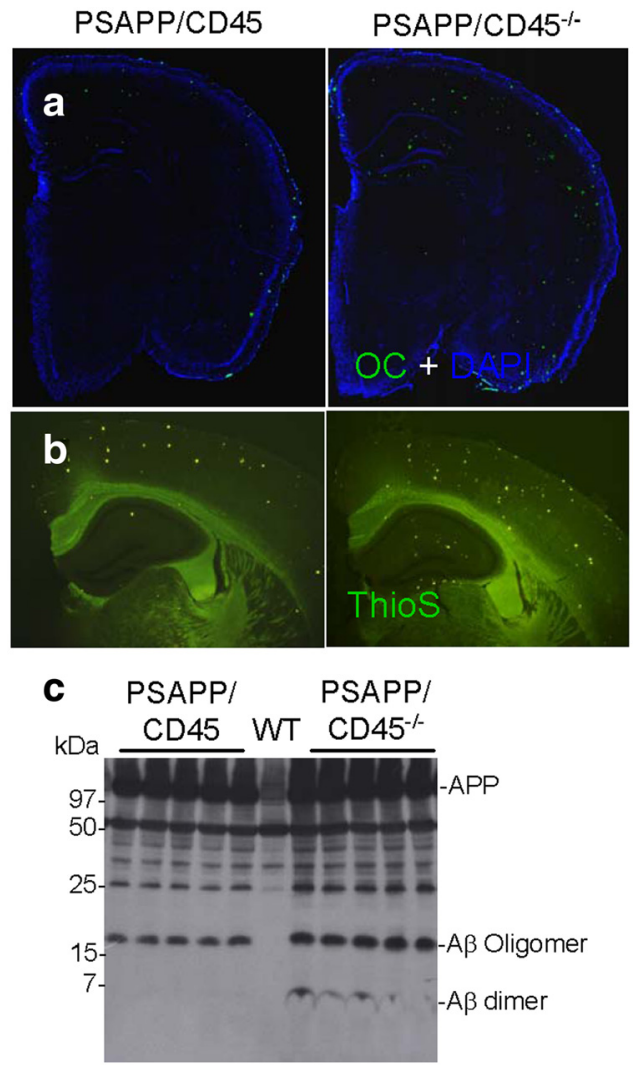

Figure 1. Accelerated cerebral amyloidosis in $P S A P P / C D 45^{-/-}$mice. $\boldsymbol{a}, \boldsymbol{b}$, Mouse brain sections from PSAPP/CD45 and PSAPP/CD $45^{-/-}$mice stained with $A \beta O C$ antibody (green signal) and DAPI (blue signal) at 4 months of age (a) or ThioS at 8 months of age (b)., , Brain homogenates were prepared from 8-month-old wild-type (WT), PSAPP/CD45, or PSAPP/ CD $45^{-/-}$mice. Western blot by antibody $6 \mathrm{E} 10$ shows increased abundance of dimeric and oligomeric $A \beta$ species in brain homogenates from PSAPP/CD45 $5^{-/}$versus PSAPP/CD45 or wild-type mice.

attributable to differences in APP transgene expression or A $\beta$ metabolism (data not shown).

$\mathrm{A} \beta$ peptides are metastable and can exist as monomeric, dimeric, and higher-molecular-weight oligomeric forms both in vitro and in vivo (Selkoe, 2001; Klyubin et al., 2005; Walsh et al., 2005; Shankar et al., 2008). It is becoming clear that $\mathrm{A} \beta$ dimers and oligomers are likely the neurotoxic species, because direct in vivo administration of these $\mathrm{A} \beta$ conformers injures neurons (Shankar et al., 2008). To determine whether CD45 deficiency impacted the metastable equilibrium of $\mathrm{A} \beta$, we probed brain homogenates from PSAPP/CD 45 or PSAPP/CD $45^{-/-}$mice at 4 and 8 months of age by Western immunoblot. $A \beta$ oligomers were increased in PSAPP/CD $45^{-/-}$mice at 4 months of age (supplemental Fig. $1 c$, available at www.jneurosci.org as supplemental material). Strikingly, both dimeric and oligomeric A $\beta$ species were elevated in PSAPP/CD $45^{-/-}$versus PSAPP/CD45 mice at 8 months of age (Fig. 1c). Together, these results indicate that cerebral $\mathrm{A} \beta$ pathology is overrepresented in CD45-deficient PSAPP mice.

\section{Impaired brain-to-blood $\mathrm{A} \beta$ clearance in aged PSAPP $/ C D 45^{-1-}$ mice}

It has been proposed that cerebral $A \beta$ is cleared across the bloodbrain barrier (BBB) via a "peripheral sink," and there is evidence of dysfunctional brain-to-blood $\mathrm{A} \beta$ clearance in $\mathrm{AD}$ patients and in transgenic mouse models of the disease (DeMattos et al., 2001; a

Brain insoluble $A \beta$ species

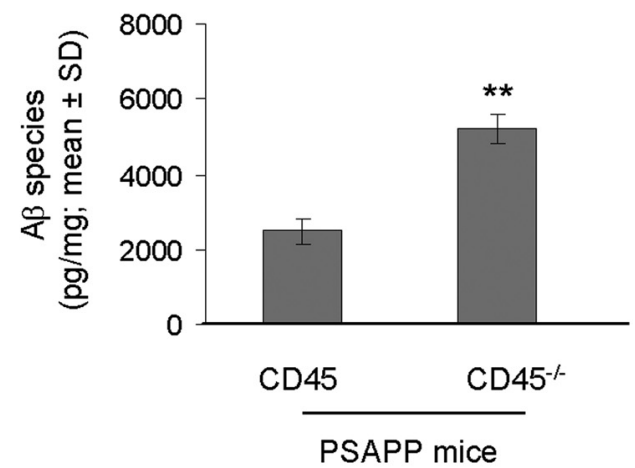

b Brain soluble $A \beta$

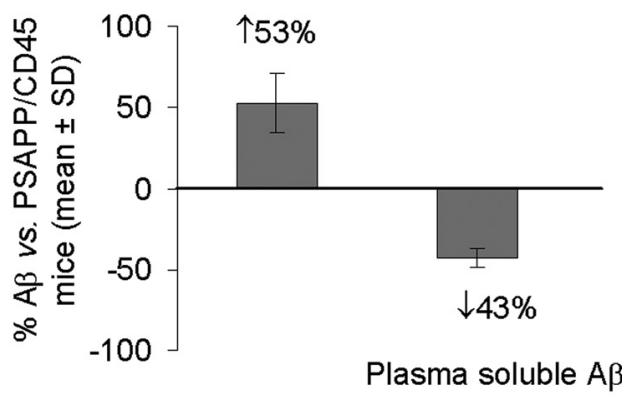

PSAPP/CD $45^{-/-}$mice

Figure 2. Simultaneously increased central and reduced peripheral $A \beta$ in $P S A P P / C D 45^{-/-}$ mice. Mouse brain homogenates were prepared from PSAPP/CD45 $5^{-/}$and PSAPP/CD45 mice at 4 months of age. $\boldsymbol{a}$, Detergent-insoluble ( $5 \mathrm{~m}$ guanidine-soluble) total $A \beta$ species (including $A \beta_{1-40,42}$; icograms per milligrams of protein) were biochemically assessed in brain homogenates by ELISA. Data are presented as mean $\pm S D$ ( $n=8$ females per group). $\boldsymbol{b}$, We also analyzed steady-state cerebral and plasma total soluble $A \beta$ species (including $A \beta_{1-40,42}$ ) at the time of death by ELISA. A $\beta$ levels are represented as percentages versus PSAPP/CD45 mice with mean $\pm S D\left(n=8\right.$ females per group). ${ }^{* *} p<0.01$.

Deane et al., 2003). To determine whether CD45 deficiency impacted relative $\mathrm{A} \beta$ abundance in cerebral and systemic compartments, we probed brains and plasma from CD45deficient and -sufficient PSAPP mice using a biochemical approach. We assessed total insoluble $\mathrm{A} \beta$ species (including $\mathrm{A} \beta_{1-40}$ and $\left.\mathrm{A} \beta_{1-42}\right)$ in PSAPP/CD $45^{-/-}$and PSAPP/CD45 mouse brain homogenates at 4 and 8 months of age by ELISA. Analysis of 4 -month-old mouse brains revealed significantly $\left({ }^{* *} p<0.01\right)$ elevated abundance of insoluble $\mathrm{A} \beta$ species in CD45-deficient versus -sufficient PSAPP mice (Fig. $2 a$ ), although this difference was not evident in 8 -month-old brains (supplemental Fig. $2 a$, available at www.jneurosci.org as supplemental material). Correspondingly, cerebral detergent-soluble $\mathrm{A} \beta$ species were increased whereas plasma-soluble $\mathrm{A} \beta$ abundance was diminished by a similar magnitude at both 4 and 8 months of age in $P S A P P / C D 45^{-/-}$ versus PSAPP/CD45 animals (Fig. 2b) (supplemental Fig. 2b, available at www.jneurosci.org as supplemental material). Together, these results suggest that $P S A P P / C D 45^{-/-}$mice have impaired brain-to-blood $\mathrm{A} \beta$ clearance.

\section{CD45 deficiency promotes inflammatory microglia in PSAPP mice}

Microglia are activated in close vicinity of $\beta$-amyloid plaques in $\mathrm{AD}$ patient brains and in transgenic mouse models of the disease (Benzing et al., 1999; Jimenez et al., 2008; Mandrekar-Colucci 
a PSAPP/CD45

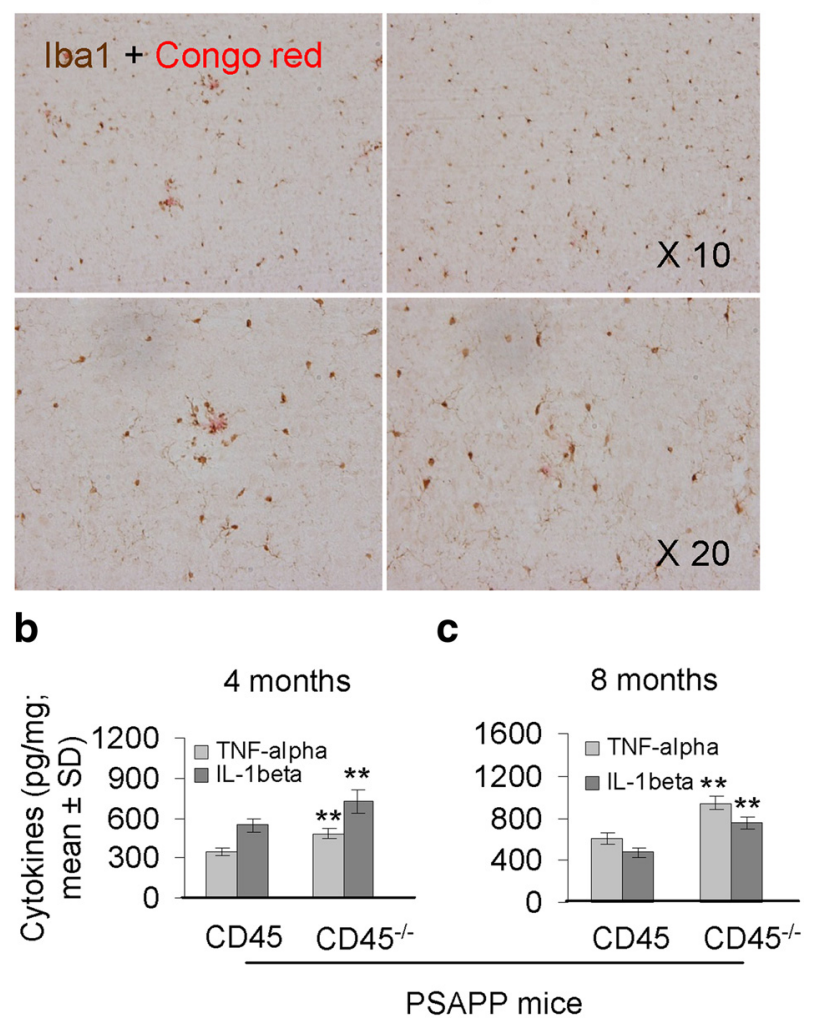

Figure 3. $P S A P P / C D 45^{-1-}$ mice have an inflammatory microglial phenotype. $\boldsymbol{a}$, Mouse brain sections from 8-month-old PSAPP/CD45 or PSAPP/CD45 ${ }^{-/-}$mice were double-labeled with Iba1 antibody and Congo red. $\boldsymbol{b}, \boldsymbol{c}$, The microglial proinflammatory cytokines TNF- $\alpha$ and IL-1 $\beta$ were quantified in brain homogenates from both PSAPP/CD 45 and PSAPP/CD $45^{-1-}$ mice at $4(\boldsymbol{b})$ and $8(\boldsymbol{c})$ months of age by ELISA. Data are represented as mean \pm SD $(n=8$ female mice per group) for each cytokine (picograms per milligrams of protein). ${ }^{* *} p<0.01$.

and Landreth, 2010). Although it was once thought that microglial "activation" was a single phenotype, we now know that multiple forms of functionally distinct reactive microglia exist (Town et al., 2005; Colton, 2009; Colton and Wilcock, 2010). To determine whether CD45 deficiency impacted microglial phenotype in PSAPP mice, we stained brain sections from PSAPP/CD45 and $P S A P P / C D 45^{-1-}$ mice with antibodies directed against the activated microglial markers Iba1, CD11b, or CD40 (Tan et al., 1999; Townsend et al., 2005; Ahmed et al., 2007), in combination with $\mathrm{A} \beta$ antibody 4G8 and DAPI as a nuclear counterstain. Because microglia activate in response to $A \beta$ deposits and 4-month-old $P S A P P / C D 45^{-1-}$ mice had elevated $\beta$-amyloid plaque load versus controls (Fig. 1), we wanted to avoid this confounder and therefore focused on analyzing our 8-month-old cohort with minimal or no differences on insoluble $\mathrm{A} \beta$ abundance (supplemental Fig. $2 a$, available at www.jneurosci.org as supplemental material). As shown in Figure 3a, Ibal-positive microglia were generally found in close spatial proximity to cortical $\mathrm{A} \beta$ plaque centers in PSAPP/CD45 mice, whereas PSAPP/CD $45^{-1-}$ animals displayed a more random and diffuse pattern of parenchymal Iba1 reactivity. Furthermore, the distance between each microglial cell to the center of the nearest Congo red-positive $A \beta$ plaque was measured in brain sections from 8-month-old $P S A P P / C D 45^{-/-}$versus PSAPP/CD45 mice. At the quantitative level, Iba1-positive cells were significantly $\left({ }^{*} p<0.01\right)$ farther away from $\mathrm{A} \beta$ deposits when comparing PSAPP/CD $45^{-1-}$ with PSAPP/CD45 mice. The diffuse nature of Iba1-positive microglia in $P S A P P / C D 45^{-1-}$ mice seems consistent with a "runaway" proinflammatory state that is poorly directed toward amyloid plaques in these mice. Similar results were observed in PSAPP/ $C D 45^{-1-}$ mice at 4 months of age, despite imbalance in cerebral amyloidosis in this cohort (data not shown).

We have shown that immunological costimulation via the CD40 pathway enables microglial inflammatory responses after $\mathrm{A} \beta$ peptide stimulation and also reduces $\mathrm{A} \beta$ clearance responses by these cells (Tan et al., 1999, 2002; Townsend et al., 2005). Consistent with a proinflammatory but anti-A $\beta$ phagocytic microglial phenotype, $\mathrm{A} \beta$ plaque-associated microglia in PSAPP/ $C D 45^{-/-}$brains loose CD11b signal but gain expression of CD40 (supplemental Fig. $3 a$, available at www.jneurosci.org as supplemental material). Quantification of these results revealed a statistically significant $\left({ }^{* *} p<0.005\right)$ reduction in $\mathrm{CD} 11 \mathrm{~b}$ but significantly $\left({ }^{* *} p<0.01\right)$ increased CD40 signal in PSAPP/ $C D 45^{-/}$versus PSAPP/CD45 mouse brains (supplemental Fig. $3 b$, available at www.jneurosci.org as supplemental material). To further assess brain inflammation, we measured the microglial proinflammatory cytokines TNF- $\alpha$ and IL- $1 \beta$ in brain homogenates from PSAPP/CD45 and PSAPP/CD $45^{-1-}$ mice at 4 and 8 months of age. Consistent with our histological observations, data revealed significantly $\left({ }^{* *} p<0.01\right)$ increased levels of both cytokines in CD45-deficient versus -sufficient PSAPP mice at both ages (Fig. $3 b, c)$. When taken together with the above $\mathrm{A} \beta$ plaque microglial localization findings, these results suggest that CD45 deficiency promotes an inflammatory microglial phenotype that is inefficient at restricting cerebral amyloidosis and promotes buildup of neurotoxic $A \beta$ oligomers.

To better characterize whether CD45 deficiency affected microglia or blood-borne monocytes/macrophages (or both), we took an immunofluorescence approach based on morphologic and immunophenotypic criteria to critically examine brain sections for any evidence of hematogenously derived immune cells (El Khoury et al., 2007; Town et al., 2008). This methodology was chosen over irradiation/bone marrow chimeras, because the latter have become controversial. Specifically, the act of irradiating mice artificially sensitizes the CNS to large-scale infiltration and engraftment of the adoptively transferred peripheral macrophages (Ahmed et al., 2007; Mildner et al., 2007). Despite careful determination of CD3, CD4, CD45 (data not shown), Ibal, $\mathrm{CD} 11 \mathrm{c}$, and $\mathrm{Ccr} 2$ expression and inclusion of an experimental autoimmune encephalomyelitis-positive control, we were unable to detect blood-derived immune cells in any of the four mouse groups analyzed (supplemental Fig. 4, available at www.jneurosci.org as supplemental material).

\section{$C D 45^{-/-}$microglia have impaired $\mathrm{A} \boldsymbol{\beta}_{1-42}$ phagocytosis}

Although there has been much recent debate about whether microglia are efficient $\mathrm{A} \beta$ phagocytes (Grathwohl et al., 2009), microglial $\mathrm{A} \beta$ phagocytosis has nonetheless been suggested to occur to a limited extent in the AD brain (Familian et al., 2007), and we have shown recently that peripherally derived mononuclear phagocytes can clear oligomeric A $\beta$ species (Town et al., 2008). Our in vivo results suggested that $\mathrm{CD} 45$ deficiency promoted a proinflammatory yet anti-A $\beta$ phagocytic microglial phenotype (Town et al., 2005). To determine whether CD45 agonism could produce the converse in vitro, we prepared CD45-deficient and -sufficient microglia from neonates as described previously (Zhu et al., 2008) and challenged them with agonistic CD45 antibody or isotypematched control IgG in the presence of aged FITC $-\mathrm{A} \beta_{1-42}$. As shown in Figure $4 a$, ablation of CD45 significantly $\left({ }^{* *} p<0.01\right)$ diminished microglial phagocytosis of FITC-A $\beta_{1-42}$, and addi- 
tion of agonistic CD45 antibody significantly $\left({ }^{*} p<0.05\right)$ elevated this effect in CD45-sufficient cells (but had no effect on CD45-deficient control cells). Microglia treated with a nonrelevant isotypematched IgG control antibody did not differ from untreated cells (data not shown). To validate this result, we treated primary microglia as described above and then imaged them by confocal microscopy. Data revealed FITC-A $\beta_{1-42}$ peptide within the cytoplasm of CD45-sufficient primary microglial cells, whereas the peptide remained on the surface of CD45deficient cells (Fig. 4b).

Interestingly, unlike the more ramified appearance of wild-type cells that typically indicates a "resting" state, CD45-deficient microglia had a unique morphology denoted by an ovoid cytoplasm and relatively few cytoplasmic processes compared with wild-type cells (Fig. 4b). This morphological phenotype of CD45-deficient microglia occurred in concert with strikingly increased expression of CD40 (supplemental Fig. 3, available at www.jneurosci.org as supplemental material), a key costimulatory protein required for proinflammatory innate immune activation of antigen presenting cells. Furthermore, as shown in Figure $4 b$, ovoid CD45-deficient microglia were unable to take up fluorescently tagged $\mathrm{A} \beta$ peptide in vitro. We conclude that CD45 deficiency leads to a functional switch in microglial phenotype characterized by morphologic and immunophenotypic changes consistent with an activated, proinflammatory state that is incompatible with $\mathrm{A} \beta$ clearance. Although this particular microglial phenotype seems to be deleterious in the context of $\mathrm{AD}$, it is important to note that not all forms of microglial activation are detrimental; this is underscored by findings from $\mathrm{A} \beta$ "immunotherapy" approaches, in which microglia could be stimulated to phagocytose and clear $\mathrm{A} \beta$ deposits decorated with $\mathrm{A} \beta$-specific antibodies (Schenk et al., 1999; Bard et al., 2000).

\section{Increased neuronal intracellular $\mathrm{A} \beta$ in aged $P S A P P / C D 45^{-/-}$ mice}

$\mathrm{A} \beta$ can exist in both secreted and intracellular pools within the brain (Watson et al., 2005). APP is normally metabolized to A $\beta$ via an endocytosis-dependent, $\mathrm{pH}$-sensitive pathway (Shoji et al., 1992; Koo and Squazzo, 1994), and intracellular A $\beta$ has been found in degenerating neurons in the $\mathrm{AD}$ brain (Probst et al., 1991). If CD45-deficient microglia were unable to effectively clear cerebral $\mathrm{A} \beta$, then one might expect intracellular buildup of the peptide. To evaluate this hypothesis, we investigated intracellular $\mathrm{A} \beta$ in 4 - and 8-month-old PSAPP/CD45 and PSAPP/ $C D 45^{-1-}$ brain sections by immunostaining. Regardless of age, CD45-deficient mouse brains showed a marked increase in intraneuronal 6E10 reactivity (supplemental Fig. 5a,b, available at www.jneurosci.org as supplemental material). To confirm the $\mathrm{A} \beta$ identity of these signals, we performed Western immunoblot by $6 \mathrm{E} 10$ antibody and observed that extracellular and intracellular dimeric and oligomeric $\mathrm{A} \beta$ species were increased in PSAPP/ $C D 45^{-/-}$versus PSAPP/CD45 mice at 8 months (Fig. $5 a$ ), and a similar pattern of results was also likely the case at 4 months of age (supplemental Fig. $5 c$, available at www.jneurosci.org as supplemental material), although we were working at the detection limit for the assay at this earlier age. Additionally, we quantified extracellular and intracellular soluble $\mathrm{A} \beta$ from PSAPP/CD 45 and PSAPP $/ C D 45^{-/-}$mouse brains by ELISA. Data revealed significantly $\left({ }^{\star} p<0.05 ;{ }^{* *} p<0.01\right)$ increased abundance of total soluble intracellular A $\beta$ species in PSAPP/CD $45^{-/-}$versus PSAPP/ CD45 mice at both ages and in both fractions (Fig. $5 b$ ).

\section{PSAPP $/ C D 45^{-/-}$mice have neuronal loss}

An important hallmark of $\mathrm{AD}$ is loss of neurons, resulting in significant atrophy of the cerebral cortex and certain subcortical regions, including the temporal lobe, parietal lobe, parts of the frontal cortex, and the cingulate gyrus (Wenk, 2003). As detailed above, intraneuronal $\mathrm{A} \beta$ is increased in $P S A P P / C D 45^{-/-}$mice, and we sought to investigate whether this form of $A \beta$ pathology was accompanied by neuronal loss. We reacted brain sections from 8-month-old wild-type (data not shown), $C D 45^{-/-}$, 

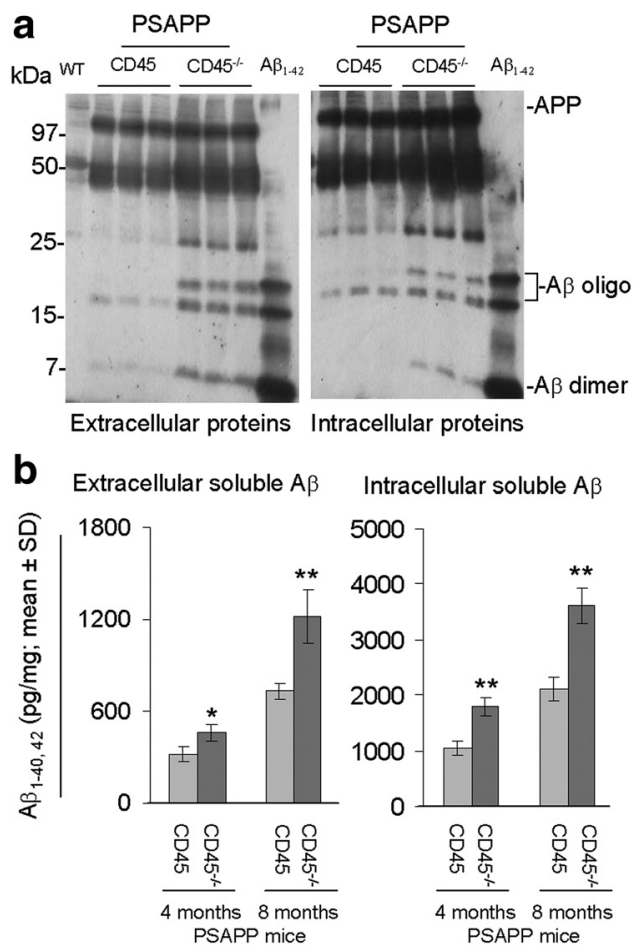

Figure 5. Increased intracellular $A \beta$ in $P S A P P / C D 45^{-/-}$mice. $\boldsymbol{a}$, Extracellular and intracellular proteins were prepared from 8-month-old wild-type (WT), PSAPP/CD45, and PSAPP/CD45 ${ }^{-/-}$ mouse brain homogenates. Western blot analysis by antibody 6 E10 shows increased abundance of $A \beta$ dimers and oligomers in brain extracts from PSAPP/CD $45^{-/-}$versus PSAPP/CD45 or wild-type mice. $\boldsymbol{b}$, Total detergent-soluble $A \beta$ species (including $A \beta_{1-40,42}$ ) in extracellular or intracellular fractions were assayed in 4 - and 8-month-old PSAPP/CD45 and PSAPP/CD45 ${ }^{-/-}$mouse brain extracts by ELISA. Results are represented as mean $\pm S D$ ( $n=8$ females per group) of total soluble $A \beta$ species (picograms per milligrams of protein). ${ }^{*} p<0.05,{ }^{* *} p<0.01$.

PSAPP/CD45, or PSAPP/CD45 ${ }^{-/-}$mice with Nissl or NeuN antibody and performed stereological analysis for NeuN-positive cells. Nissl staining revealed neuronal dysmorphology suggestive of neuronal degeneration (Fig. 6a). Furthermore, NeuN immunohistochemistry disclosed a more rarefied pattern of neurons in PSAPP $/ C D 45^{-/-}$mice (Fig. $6 b$ ), and stereological analysis demonstrated significantly $\left({ }^{*} p<0.05\right)$ decreased NeuN-positive cells in the medial entorhinal cortex (Fig. $6 c$ ) of $P S A P P / C D 45^{-/-}$versus PSAPP/CD45 or control CD $45^{-/-}$mice at 8 months of age, but this was not yet evident in 4-month-old animals (data not shown).

To validate these results, we prepared brain homogenates from each group of mice at 8 months of age. Western blot analysis revealed decreased levels of NeuN relative to actin (Fig. $6 d$ ) in PSAPP $/ C D 45^{-/-}$versus PSAPP/CD 45 or control CD $45^{-/-}$mice. A similar pattern of results was noted when considering expression ratio of the neuronal anti-apoptotic regulator Bcl-xL (Parsadanian et al., 1998) to the proapoptotic protein Bax (Fig. 6d). Furthermore, another index of apoptosis, cleaved caspase-3, was overrepresented in PSAPP/CD $45^{-/-}$mice compared with the other two mouse groups, whereas unprocessed caspase-3 did not differ between groups (Fig. 6e). When taken together, these results demonstrate neuronal loss in PSAPP/CD $45^{-/-}$mice, likely as a result of apoptosis.

\section{Mitochondrial dysfunction in PSAPP/CD $45^{-/-}$mice}

The brain is highly dependent on aerobic metabolism, and mitochondria are responsible for cellular respiration. To investigate whether neuronal loss in PSAPP/CD $45^{-/-}$mice was accompa- nied by loss of mitochondrial function, we isolated mitochondria from cortical regions (including frontal, entorhinal, and cingulate cortices) and hippocampi of 8-month-old wild-type, $C D 45^{-/-}$, PSAPP/CD45, and PSAPP/CD $45^{-/-}$mice. We then enumerated respiratory rates for each brain region in all mouse groups. We observed significantly $\left({ }^{*} p<0.05\right.$; $\left.{ }^{* *} p<0.01\right)$ reduced basal (state II) respiration (supplemental Fig. $6 a$, left panels, available at www.jneurosci.org as supplemental material) and attenuated maximum respiratory rate (supplemental Fig. $6 a$, right panels, available at www.jneurosci.org as supplemental material) in PSAPP/CD $45^{-/-}$mice versus the three other groups for all brain regions examined. Furthermore, mitochondrial membrane potential (supplemental Fig. $6 b$, left panels, available at www.jneurosci.org as supplemental material) and reactive oxygen species abundance (supplemental Fig. 6b, right panels, available at www.jneurosci.org as supplemental material) were significantly $\left({ }^{*} p<0.05 ;{ }^{* *} p<0.01\right)$ reduced in PSAPP $/ C D 45^{-/-}$ compared with wild-type, CD $45^{-/-}$, or PSAPP/CD45 mice for mitochondria isolated from either cortical or hippocampal brain regions. These results indicate that $P S A P P / C D 45^{-1-}$ mice exhibit mitochondrial dysfunction, which dovetails with shift from antiapoptotic to proapoptotic proteins and neuronal loss in these animals.

\section{Discussion}

There has been considerable recent debate surrounding the relationship between microglia and AD-like pathology. Although microglia in brains of healthy elderly individuals are uniformly distributed, these cells appear in tight temporal and spatial proximity to amyloid plaques in brains of AD patients and in transgenic mouse models of the disease (McGeer et al., 1987; Benzing et al., 1999; Akiyama et al., 2000; Heneka and O'Banion, 2007). These pathological observations have prompted the conclusion that microglia are etiological participants in $\mathrm{AD}$, although this remains controversial (Grathwohl et al., 2009). In support of this notion, studies that impair microglial or mononuclear phagocyte functions by (1) treatment with nonsteroidal anti-inflammatory drugs (Lim et al., 2000, 2001), (2) interrupting CD40-CD40L interaction (Tan et al., 1999,2002), or (3) genetically ablating transforming growth factor- $\beta$ (TGF- $\beta$ ) receptor signaling (Town et al., 2008) mitigate $\mathrm{AD}$-like pathology in transgenic $\mathrm{AD}$ mice. Additionally, immunotherapy approaches that rely on $\mathrm{A} \beta$ specific antibodies to stimulate microglial clearance of $\mathrm{A} \beta$ deposits resolve AD-like pathology in mouse models (Schenk et al., 1999; Bard et al., 2000). However, deficiency of the Ccr2 chemokine receptor reduces microglial recruitment to brains of $\mathrm{AD}$ model mice and causes accumulation of cerebral amyloid plaques (El Khoury et al., 2007), whereas genetic ablation of the CX3 $\mathrm{cr} 1$ fractalkine receptor impairs microglial migration to neurons "marked for death" and prevents neuronal loss in 3xTg-AD mice (Fuhrmann et al., 2010). A parsimonious conclusion that arises from these results is that multiple forms of microglial activation exist, some being deleterious and others, beneficial (Town et al., 2005; Wyss-Coray, 2006).

CD45 is the most abundant membrane-bound protein tyrosine phosphatase and functions to dampen overly exuberant immune responses (Justement, 1997). Furthermore, microglial CD45 abundance is increased in brains of AD patients and in mouse models of the disease (Masliah et al., 1991; Licastro et al., 1998). Although multiple variants of CD45 are generated by alternate mRNA splicing, the CD45RB isoform is most highly expressed by microglia (Townsend et al., 2004). Microglial CD45 functions to inhibit nitric oxide and TNF- $\alpha$ production induced 
a

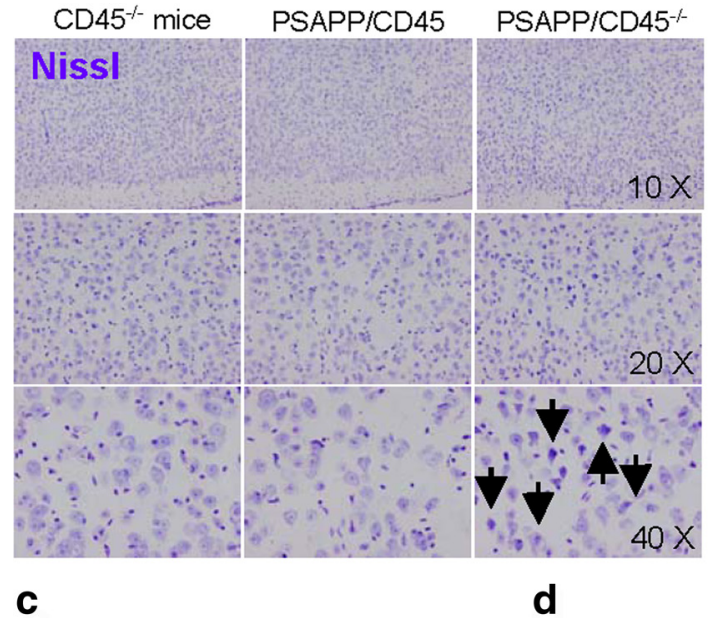

C

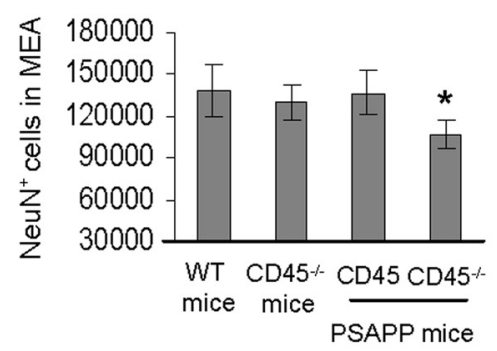

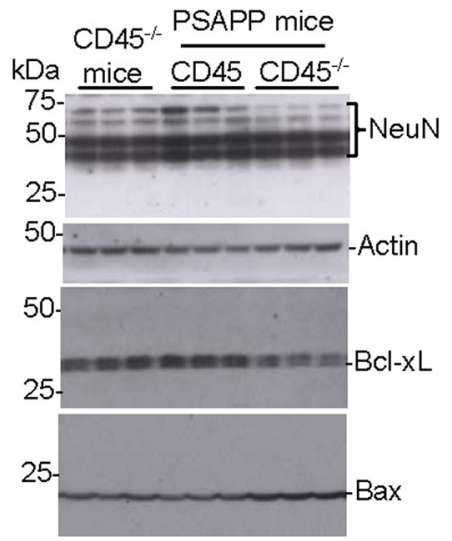

b

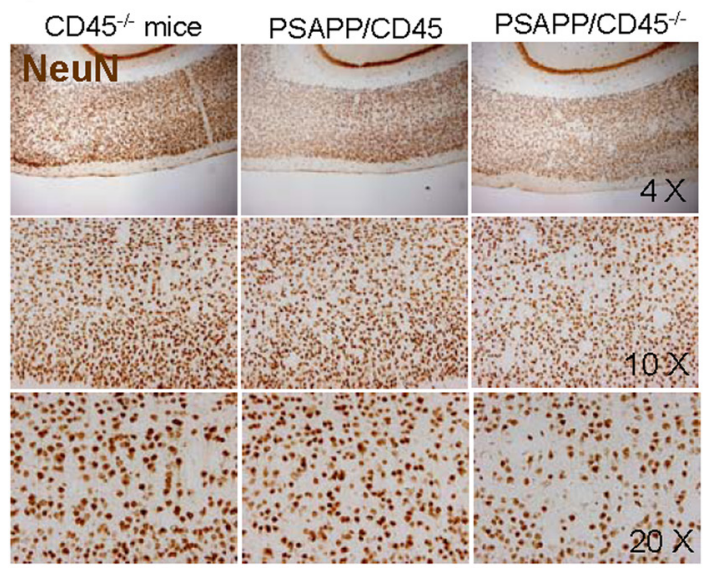

e

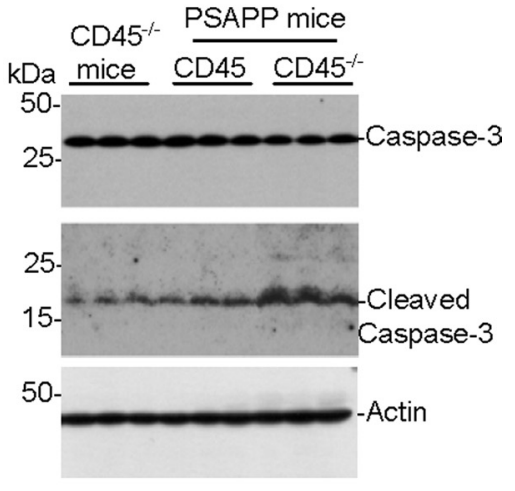

Figure 6. $\quad \boldsymbol{a}, \boldsymbol{b}$, PSAPP/CD45 $5^{-/-}$mice have neuronal injury and loss. Mouse brain sections from 8 -month-old $C D 45^{-/-}$, PSAPP/CD45, and PSAPP/CD45 ${ }^{-/-}$mice were stained with Nissl (dysmorphic neurons are indicated by arrows) (a) or NeuN antibody $(\boldsymbol{b})$, and representative entorhinal cortex images are shown. $\boldsymbol{c}$, Stereological analysis for NeuN-positive cells in the medial entorhinal cortex (MEA) ( $n=6$ female mice per group; mean \pm SD) is graphically represented. $\boldsymbol{d}, \boldsymbol{e}$, Brain homogenates were prepared from 8-month-old control CD45 ${ }^{-/-}$, PSAPP/CD45, and PSAPP/CD45 $5^{-1-}$ mice and probed by Western blot using antibodies against NeuN, Bcl-xL, or Bax (d) total and cleaved (active) caspase-3 (e). Note reduced expression of NeuN and Bcl-xL and increased abundance of Bax protein and cleaved caspase-3 in PSAPP/CD $45^{-/-}$versus PSAPP/CD45 or CD45 $5^{-1}$ mouse brains. WT, Wild type. ${ }^{*} p<0.05$.

by $\mathrm{A} \beta$ peptides (Tan et al., 2000b), CD40L, or bacterial endotoxin by dephosphorylating Src-family kinases and thereby inactivating p44/42 and p38 MAPKs (Zhu et al., 2008). In vitro, we have suggested that $\mathrm{CD} 45 \mathrm{RB}$ on microglia likely acts as a molecular switch to turn phagocytosis "off" and damaging proinflammatory response "on" in the presence of exogenous A $\beta$ (Zhu et al., 2008).

To explore the functional consequences of CD 45 deficiency in vivo, we crossed transgenic mice overproducing $\mathrm{A} \beta$ with animals deficient in CD45. PSAPP/CD $45^{-/-}$mice manifest accelerated cerebral amyloidosis, characterized by elevated abundance of $\beta$-amyloid plaques and both intracellular and extracellular pools of soluble, oligomeric, and insoluble $\mathrm{A} \beta$. Although soluble intraneuronal forms of $\mathrm{A} \beta$ are produced under physiologic conditions, a tight balance exists between peptide production and clearance (Shoji et al., 1992; Koo and Squazzo, 1994); yet, abnormally high amounts of intracellular $\mathrm{A} \beta$ are present in degenerating neurons in brains of AD and Down's syndrome patients (Allsop et al., 1989; Probst et al., 1991), in monkey and rodent models of $\mathrm{A} \beta$ deposition (Martin et al., 1994), and in human immunodeficiency virus patients with dementia (Green et al., 2005). Intracellular $A \beta$ is produced in the endoplasmic reticulum and Golgi complex in neuronal cells (Wertkin et al., 1993; WildBode et al., 1997; Xu et al., 1997), and A $\beta$ immunoreactivity within lysosomes of degenerating neurons has been found in both aging macaques (Martin et al., 1994) and in A $\beta$-infused rats (Frautschy et al., 1996). Our results from PSAPP/CD $45^{-/-}$mice lend support to the idea that intraneuronal $A \beta$ accumulation precedes neuronal loss, as recently suggested by another group (Fuhrmann et al., 2010).

But what form of $\mathrm{A} \beta$ is neurotoxic? Recent focus has shifted toward soluble oligomeric $\mathrm{A} \beta$ species as the agents of neurotoxicity. Administration of $\mathrm{A} \beta$ oligomers directly isolated from $\mathrm{AD}$ patient cerebral cortices to normal rats impaired long-term potentiation, enhanced long-term depression, and reduced dendritic spine density. Furthermore, these deleterious effects were specifically attributable to $\mathrm{A} \beta$ dimers (Shankar et al., 2008), and it is likely that $A \beta$-directed immunotherapy works by clearing oligomeric species of A $\beta$ (Klyubin et al., 2005). However, do mononuclear phagocytes including microglia impact steady-state $\mathrm{A} \beta$ oligomer abundance? We previously showed that blockade of TGF- $\beta$-Smad $2 / 3$ signaling promotes uptake and clearance of A $\beta$ oligomers by cells of mononuclear phagocyte origin (Town et al., 2008), and the present work demonstrates that CD45 deficiency drives accumulation of cerebral $\mathrm{A} \beta$ dimers and oligomers in a transgenic mouse model of $\mathrm{AD}$. Results presented here place microglia on the $A \beta$ oligomer clearance pathway and suggest that ablating CD45 and thereby inhibiting this clearance machinery 
causes buildup of neurotoxic $\mathrm{A} \beta$ oligomers and neuropathology downstream of the amyloid cascade (Hardy and Allsop, 1991).

A number of studies have shown that the BBB is responsible for elimination of human $\mathrm{A} \beta$ from the brain into the blood (Shibata et al., 2000; Shiiki et al., 2004; Terasaki and Ohtsuki, 2005). Some have even harnessed this peripheral sink to clear cerebral amyloid by passive $A \beta$ immunotherapy (DeMattos et al., 2001; DeMattos et al., 2002). A $\beta$ transport across the BBB is bidirectional because, when exogenous human $A \beta_{1-40}$ is systemically injected, it is transported into the brain (Martel et al., 1997; Wengenack et al., 2000; Deane et al., 2003). As such, A $\beta$ BBB transport homeostasis is likely an important factor governing accumulation of cerebral $A \beta$ (Ito et al., 2006). In addition to elevated cerebral amyloidosis, PSAPP/CD $45^{-/-}$mice also demonstrate decreased plasma-soluble $\mathrm{A} \beta$ abundance, likely reflective of diminished brain-to-blood $\mathrm{A} \beta$ efflux. Given the exquisite microglial specificity of CD45 expression in the brain, it is unlikely that CD45 deficiency directly impacts $\mathrm{A} \beta$ clearance at the BBB. A more likely possibility consistent with our observations is that failure in microglial A $\beta$ clearance in PSAPP $/ C D 45^{-/-}$mice overloads brain-to-blood $A \beta$ efflux machinery, leading to increased cerebral amyloid and reduced circulating $\mathrm{A} \beta$.

In addition to accelerated cerebral amyloidosis, we also find increased abundance of TNF- $\alpha$ and IL- $1 \beta$ [which are neurotoxic at high levels (Meda et al., 1995; Barger and Harmon, 1997; Tan et al., 1999)], mitochondrial dysfunction, and neuronal loss in PSAPP $/ C D 45^{-/-}$mice. Association among these three observations leads to a model wherein CD45 deficiency endorses a proinflammatory but anti-A $\beta$ phagocytic form of microglial activation. Because of failed microglial clearance of cerebral $\mathrm{A} \beta$ and overexpression of neurotoxic cytokines, downstream events in this model would include dysfunctional mitochondrial respiration and ultimately neuronal loss. However, it is unclear whether mitochondrial dysfunction brought on by loss of CD45 is a cause or consequence of neurotoxicity. In this regard, oxidative phosphorylation-and in particular cytochrome $c$ oxidase activity-is deficient in AD patient brains (Cottrell et al., 2001; Fukui et al., 2007). However, falloff in cytochrome $c$ oxidase activity is likely related to global decline in numbers of mitochondria as a result of neurotoxicity. A number of factors might contribute to the observed reduction in oxidative phosphorylation activity in $\mathrm{AD}$, including failed mitochondrial transport through axonal and dendritic processes, compromised regulatory feedback mechanisms responsible for individual complexsubunit synthesis, and impaired complex assembly (Mancuso et al., 2008).

It is well established that CD45 has multiple splice variants (chiefly, -RA, -RB, -RC, and -RO), that are variously expressed by different immune cells. CD45 isoforms may functionally differ, and this explains why gross CD45 deficiency can lead to both hypo- and hyper-responsive immunological defects. We previously demonstrated that, in the case of microglia, 90\% of CD45 can be accounted for by the CD45RB isoform (Townsend et al., 2004). Furthermore, although agonistic antibodies directed against CD45RA or CD45RC isoforms had minimal effects on lipopolysaccharide-induced microglial activation, antibodymediated stimulation of CD45RB resulted in almost complete shutdown of lipopolysaccharide-induced TNF- $\alpha$ release in cultured microglia (Townsend et al., 2004; Zhu et al., 2008). Finally, stimulation of CD45RB specifically enhanced $A \beta$ uptake that was dependent on inhibition of the p44/42 MAPK signaling cascade (Zhu et al., 2008). Nonetheless, future studies including phenotypic analyses of each CD45 isoform in the absence of alternative variants will be needed to determine the functional implications of the various CD45 isoforms vis-à-vis microglial biology.

Our present work demonstrates that genetic loss of CD45 (1) accelerates cerebral amyloidosis, (2) causes brain accumulation of soluble oligomeric $A \beta$ species and reduction in plasma-soluble $\mathrm{A} \beta$, (3) promotes proinflammatory and anti-A $\beta$ phagocytic microglial activation, and (4) leads to mitochondrial dysfunction and neuronal loss in PSAPP/CD $45^{-/-}$mice. If this mouse model translates to the clinical syndrome, then a pharmacotherapeutic strategy aimed at promoting CD45-mediated microglial $\mathrm{A} \beta$ clearance should be beneficial for AD treatment.

\section{References}

Ahmed Z, Shaw G, Sharma VP, Yang C, McGowan E, Dickson DW (2007) Actin-binding proteins coronin-1a and IBA-1 are effective microglial markers for immunohistochemistry. J Histochem Cytochem 55:687-700.

Akiyama H, Barger S, Barnum S, Bradt B, Bauer J, Cole GM, Cooper NR, Eikelenboom P, Emmerling M, Fiebich BL, Finch CE, Frautschy S, Griffin WS, Hampel H, Hull M, Landreth G, Lue L, Mrak R, Mackenzie IR, McGeer PL, et al. (2000) Inflammation and Alzheimer's disease. Neurobiol Aging 21:383-421.

Allsop D, Haga SI, Haga C, Ikeda SI, Mann DM, Ishii T (1989) Early senile plaques in Down's syndrome brains show a close relationship with cell bodies of neurons. Neuropathol Appl Neurobiol 15:531-542.

Bard F, Cannon C, Barbour R, Burke RL, Games D, Grajeda H, Guido T, Hu K, Huang J, Johnson-Wood K, Khan K, Kholodenko D, Lee M, Lieberburg I, Motter R, Nguyen M, Soriano F, Vasquez N, Weiss K, Welch B, Seubert P, Schenk D, Yednock T (2000) Peripherally administered antibodies against amyloid beta-peptide enter the central nervous system and reduce pathology in a mouse model of Alzheimer disease. Nat Med 6:916-919.

Barger SW, Harmon AD (1997) Microglial activation by Alzheimer amyloid precursor protein and modulation by apolipoprotein E. Nature 388:878-881.

Benatar T, Carsetti R, Furlonger C, Kamalia N, Mak T, Paige CJ (1996) Immunoglobulin-mediated signal transduction in B cells from CD45deficient mice. J Exp Med 183:329-334.

Benzing WC, Wujek JR, Ward EK, Shaffer D, Ashe KH, Younkin SG, Brunden KR (1999) Evidence for glial-mediated inflammation in aged APP(SW) transgenic mice. Neurobiol Aging 20:581-589.

Carson MJ, Reilly CR, Sutcliffe JG, Lo D (1998) Mature microglia resemble immature antigen-presenting cells. Glia 22:72-85.

Chung H, Brazil MI, Soe TT, Maxfield FR (1999) Uptake, degradation, and release of fibrillar and soluble forms of Alzheimer's amyloid beta-peptide by microglial cells. J Biol Chem 274:32301-32308.

Colton CA (2009) Heterogeneity of microglial activation in the innate immune response in the brain. J Neuroimmune Pharmacol 4:399-418.

Colton CA, Wilcock DM (2010) Assessing activation states in microglia. CNS Neurol Disord Drug Targets 9:174-191.

Cottrell DA, Blakely EL, Johnson MA, Ince PG, Turnbull DM (2001) Mitochondrial enzyme-deficient hippocampal neurons and choroidal cells in AD. Neurology 57:260-264.

Deane R, Du Yan S, Submamaryan RK, LaRue B, Jovanovic S, Hogg E, Welch D, Manness L, Lin C, Yu J, Zhu H, Ghiso J, Frangione B, Stern A, Schmidt AM, Armstrong DL, Arnold B, Liliensiek B, Nawroth P, Hofman F, Kindy M, Stern D, Zlokovic B (2003) RAGE mediates amyloid-beta peptide transport across the blood-brain barrier and accumulation in brain. Nat Med 9:907-913.

DeMattos RB, Bales KR, Cummins DJ, Dodart JC, Paul SM, Holtzman DM (2001) Peripheral anti-A beta antibody alters CNS and plasma A beta clearance and decreases brain A beta burden in a mouse model of Alzheimer's disease. Proc Natl Acad Sci U S A 98:8850-8855.

DeMattos RB, Bales KR, Cummins DJ, Paul SM, Holtzman DM (2002) Brain to plasma amyloid-beta efflux: a measure of brain amyloid burden in a mouse model of Alzheimer's disease. Science 295:2264-2267.

El Khoury J, Toft M, Hickman SE, Means TK, Terada K, Geula C, Luster AD (2007) Ccr2 deficiency impairs microglial accumulation and accelerates progression of Alzheimer-like disease. Nat Med 13:432-438.

Familian A, Eikelenboom P, Veerhuis R (2007) Minocycline does not affect amyloid beta phagocytosis by human microglial cells. Neurosci Lett 416:87-91. 
Frackowiak J, Wisniewski HM, Wegiel J, Merz GS, Iqbal K, Wang KC (1992) Ultrastructure of the microglia that phagocytose amyloid and the microglia that produce beta-amyloid fibrils. Acta Neuropathol 84:225-233.

Frautschy SA, Yang F, Calderón L, Cole GM (1996) Rodent models of Alzheimer's disease: rat A beta infusion approaches to amyloid deposits. Neurobiol Aging 17:311-321.

Fuhrmann M, Bittner T, Jung CK, Burgold S, Page RM, Mitteregger G, Haass C, LaFerla FM, Kretzschmar H, Herms J (2010) Microglial Cx3cr1 knockout prevents neuron loss in a mouse model of Alzheimer's disease. Nat Neurosci 13:411-413.

Fukui H, Diaz F, Garcia S, Moraes CT (2007) Cytochrome c oxidase deficiency in neurons decreases both oxidative stress and amyloid formation in a mouse model of Alzheimer's disease. Proc Natl Acad Sci U S A 104:14163-14168.

Glabe CG (2008) Structural classification of toxic amyloid oligomers. J Biol Chem 283:29639-29643.

Grathwohl SA, Kälin RE, Bolmont T, Prokop S, Winkelmann G, Kaeser SA, Odenthal J, Radde R, Eldh T, Gandy S, Aguzzi A, Staufenbiel M, Mathews PM, Wolburg H, Heppner FL, Jucker M (2009) Formation and maintenance of Alzheimer's disease beta-amyloid plaques in the absence of microglia. Nat Neurosci 12:1361-1363.

Green DA, Masliah E, Vinters HV, Beizai P, Moore DJ, Achim CL (2005) Brain deposition of beta-amyloid is a common pathologic feature in HIV positive patients. AIDS 19:407-411.

Hardy J, Allsop D (1991) Amyloid deposition as the central event in the aetiology of Alzheimer's disease. Trends Pharmacol Sci 12:383-388.

Heneka MT, O’Banion MK (2007) Inflammatory processes in Alzheimer's disease. J Neuroimmunol 184:69-91.

Irie-Sasaki J, Sasaki T, Matsumoto W, Opavsky A, Cheng M, Welstead G, Griffiths E, Krawczyk C, Richardson CD, Aitken K, Iscove N, Koretzky G, Johnson P, Liu P, Rothstein DM, Penninger JM (2001) CD45 is a JAK phosphatase and negatively regulates cytokine receptor signalling. Nature 409:349-354.

Ito S, Ohtsuki S, Terasaki T (2006) Functional characterization of the brainto-blood efflux clearance of human amyloid-beta peptide (1-40) across the rat blood-brain barrier. Neurosci Res 56:246-252.

Jankowsky JL, Slunt HH, Ratovitski T, Jenkins NA, Copeland NG, Borchelt DR (2001) Co-expression of multiple transgenes in mouse CNS: a comparison of strategies. Biomol Eng 17:157-165.

Jimenez S, Baglietto-Vargas D, Caballero C, Moreno-Gonzalez I, Torres M, Sanchez-Varo R, Ruano D, Vizuete M, Gutierrez A, Vitorica J (2008) Inflammatory response in the hippocampus of PS1M146L/APP751SL mouse model of Alzheimer's disease: age-dependent switch in the microglial phenotype from alternative to classic. J Neurosci 28:11650-11661.

Justement LB (1997) The role of CD45 in signal transduction. Adv Immunol 66:1-65.

Kayed R, Head E, Sarsoza F, Saing T, Cotman CW, Necula M, Margol L, Wu J, Breydo L, Thompson JL, Rasool S, Gurlo T, Butler P, Glabe CG (2007) Fibril specific, conformation dependent antibodies recognize a generic epitope common to amyloid fibrils and fibrillar oligomers that is absent in prefibrillar oligomers. Mol Neurodegener 2:18.

Klyubin I, Walsh DM, Lemere CA, Cullen WK, Shankar GM, Betts V, Spooner ET, Jiang L, Anwyl R, Selkoe DJ, Rowan MJ (2005) Amyloid beta protein immunotherapy neutralizes Abeta oligomers that disrupt synaptic plasticity in vivo. Nat Med 11:556-561.

Koo EH, Squazzo SL (1994) Evidence that production and release of amyloid beta-protein involves the endocytic pathway. J Biol Chem 269:17386-17389.

Lesné S, Koh MT, Kotilinek L, Kayed R, Glabe CG, Yang A, Gallagher M, Ashe $\mathrm{KH}$ (2006) A specific amyloid-beta protein assembly in the brain impairs memory. Nature 440:352-357.

Licastro F, Mallory M, Hansen LA, Masliah E (1998) Increased levels of alpha-1-antichymotrypsin in brains of patients with Alzheimer's disease correlate with activated astrocytes and are affected by APOE 4 genotype. J Neuroimmunol 88:105-110.

Lim GP, Yang F, Chu T, Chen P, Beech W, Teter B, Tran T, Ubeda O, Ashe KH, Frautschy SA, Cole GM (2000) Ibuprofen suppresses plaque pathology and inflammation in a mouse model for Alzheimer's disease. J Neurosci 20:5709-5714.

Lim GP, Chu T, Yang F, Beech W, Frautschy SA, Cole GM (2001) The curry spice curcumin reduces oxidative damage and amyloid pathology in an Alzheimer transgenic mouse. J Neurosci 21:8370-8377.

Maier M, Peng Y, Jiang L, Seabrook TJ, Carroll MC, Lemere CA (2008)
Complement C3 deficiency leads to accelerated amyloid beta plaque deposition and neurodegeneration and modulation of the microglia/macrophage phenotype in amyloid precursor protein transgenic mice. J Neurosci 28:6333-6341.

Mancuso M, Orsucci D, Siciliano G, Murri L (2008) Mitochondria, mitochondrial DNA and Alzheimer's disease. What comes first? Curr Alzheimer Res 5:457-468.

Mandrekar-Colucci S, Landreth GE (2010) Microglia and inflammation in Alzheimer's disease. CNS Neurol Disord Drug Targets 9:156-167.

Martel CL, Mackic JB, Matsubara E, Governale S, Miguel C, Miao W, McComb JG, Frangione B, Ghiso J, Zlokovic BV (1997) Isoform-specific effects of apolipoproteins E2, E3, and E4 on cerebral capillary sequestration and blood-brain barrier transport of circulating Alzheimer's amyloid beta. J Neurochem 69:1995-2004.

Martin LJ, Pardo CA, Cork LC, Price DL (1994) Synaptic pathology and glial responses to neuronal injury precede the formation of senile plaques and amyloid deposits in the aging cerebral cortex. Am J Pathol 145:1358-1381.

Masliah E, Mallory M, Hansen L, Alford M, Albright T, Terry R, Shapiro P, Sundsmo M, Saitoh T (1991) Immunoreactivity of CD45, a protein phosphotyrosine phosphatase, in Alzheimer's disease. Acta Neuropathol $83: 12-20$.

McGeer PL, Itagaki S, Tago H, McGeer EG (1987) Reactive microglia in patients with senile dementia of the Alzheimer type are positive for the histocompatibility glycoprotein HLA-DR. Neurosci Lett 79:195-200.

Meda L, Cassatella MA, Szendrei GI, Otvos L Jr, Baron P, Villalba M, Ferrari D, Rossi F (1995) Activation of microglial cells by beta-amyloid protein and interferon-gamma. Nature 374:647-650.

Mildner A, Schmidt H, Nitsche M, Merkler D, Hanisch UK, Mack M, Heikenwalder M, Brück W, Priller J, Prinz M (2007) Microglia in the adult brain arise from Ly-6ChiCCR2+ monocytes only under defined host conditions. Nat Neurosci 10:1544-1553.

Mitrasinovic OM, Murphy GM Jr (2002) Accelerated phagocytosis of amyloid-beta by mouse and human microglia overexpressing the macrophage colony-stimulating factor receptor. J Biol Chem 277:29889-29896.

Parsadanian AS, Cheng Y, Keller-Peck CR, Holtzman DM, Snider WD (1998) Bcl-xL is an antiapoptotic regulator for postnatal CNS neurons. J Neurosci 18:1009-1019.

Penninger JM, Irie-Sasaki J, Sasaki T, Oliveira-dos-Santos AJ (2001) CD45: new jobs for an old acquaintance. Nat Immunol 2:389-396.

Probst A, Langui D, Ipsen S, Robakis N, Ulrich J (1991) Deposition of beta/A4 protein along neuronal plasma membranes in diffuse senile plaques. Acta Neuropathol 83:21-29.

Rezai-Zadeh K, Shytle D, Sun N, Mori T, Hou H, Jeanniton D, Ehrhart J, Townsend K, Zeng J, Morgan D, Hardy J, Town T, Tan J (2005) Green tea epigallocatechin-3-gallate (EGCG) modulates amyloid precursor protein cleavage and reduces cerebral amyloidosis in Alzheimer transgenic mice. J Neurosci 25:8807-8814.

Roach T, Slater S, Koval M, White L, Cahir McFarland ED, Okumura M, Thomas M, Brown E (1997) CD45 regulates Src family member kinase activity associated with macrophage integrin-mediated adhesion. Curr Biol 7:408-417.

Saura J, Tusell JM, Serratosa J (2003) High-yield isolation of murine microglia by mild trypsinization. Glia 44:183-189.

Schenk D, Barbour R, Dunn W, Gordon G, Grajeda H, Guido T, Hu K, Huang J, Johnson-Wood K, Khan K, Kholodenko D, Lee M, Liao Z, Lieberburg I, Motter R, Mutter L, Soriano F, Shopp G, Vasquez N, Vandevert C, Walker S, Wogulis M, Yednock T, Games D, Seubert P (1999) Immunization with amyloid-beta attenuates Alzheimer-disease-like pathology in the PDAPP mouse. Nature 400:173-177.

Sedgwick JD, Schwender S, Imrich H, Dörries R, Butcher GW, ter Meulen V (1991) Isolation and direct characterization of resident microglial cells from the normal and inflamed central nervous system. Proc Natl Acad Sci U S A 88:7438-7442.

Selkoe DJ (2001) Alzheimer's disease: genes, proteins, and therapy. Physiol Rev 81:741-766.

Shankar GM, Li S, Mehta TH, Garcia-Munoz A, Shepardson NE, Smith I, Brett FM, Farrell MA, Rowan MJ, Lemere CA, Regan CM, Walsh DM, Sabatini BL, Selkoe DJ (2008) Amyloid-beta protein dimers isolated directly from Alzheimer's brains impair synaptic plasticity and memory. Nat Med 14:837-842.

Shenoi H, Seavitt J, Zheleznyak A, Thomas ML, Brown EJ (1999) Regulation 
of integrin-mediated $\mathrm{T}$ cell adhesion by the transmembrane protein tyrosine phosphatase CD45. J Immunol 162:7120-7127.

Shibata M, Yamada S, Kumar SR, Calero M, Bading J, Frangione B, Holtzman DM, Miller CA, Strickland DK, Ghiso J, Zlokovic BV (2000) Clearance of Alzheimer's amyloid-ss(1-40) peptide from brain by LDL receptorrelated protein-1 at the blood-brain barrier. J Clin Invest 106:1489-1499.

Shiiki T, Ohtsuki S, Kurihara A, Naganuma H, Nishimura K, Tachikawa M, Hosoya K, Terasaki T (2004) Brain insulin impairs amyloid- $\beta_{1-40}$ clearance from the brain. J Neurosci 24:9632-9637.

Shoji M, Golde TE, Ghiso J, Cheung TT, Estus S, Shaffer LM, Cai XD, McKay DM, Tintner R, Frangione B (1992) Production of the Alzheimer amyloid beta protein by normal proteolytic processing. Science 258:126-129.

Stibenz D, Bührer C, Laufer D, Obladen M (1996) CD45 engagement induces L-selectin down-regulation. Scand J Immunol 44:37-44.

Tan J, Town T, Paris D, Mori T, Suo Z, Crawford F, Mattson MP, Flavell RA, Mullan M (1999) Microglial activation resulting from CD40-CD40L interaction after beta-amyloid stimulation. Science 286:2352-2355.

Tan J, Town T, Mullan M (2000a) CD45 inhibits CD40L-induced microglial activation via negative regulation of the $\mathrm{Src} / \mathrm{p} 44 / 42$ MAPK pathway. J Biol Chem 275:37224-37231.

Tan J, Town T, Mori T, Wu Y, Saxe M, Crawford F, Mullan M (2000b) CD45 opposes $\beta$-amyloid peptide-induced microglial activation via inhibition of p44/42 mitogen-activated protein kinase. J Neurosci 20:75877594 .

Tan J, Town T, Crawford F, Mori T, DelleDonne A, Crescentini R, Obregon D, Flavell RA, Mullan MJ (2002) Role of CD40 ligand in amyloidosis in transgenic Alzheimer's mice. Nat Neurosci 5:1288-1293.

Terasaki T, Ohtsuki S (2005) Brain-to-blood transporters for endogenous substrates and xenobiotics at the blood-brain barrier: an overview of biology and methodology. NeuroRx 2:63-72.

Thomas ML, Brown EJ (1999) Positive and negative regulation of Srcfamily membrane kinases by CD45. Immunol Today 20:406-411.

Town T, Nikolic V, Tan J (2005) The microglial "activation" continuum: from innate to adaptive responses. J Neuroinflammation 2:24.

Town T, Laouar Y, Pittenger C, Mori T, Szekely CA, Tan J, Duman RS, Flavell RA (2008) Blocking TGF-beta-Smad2/3 innate immune signaling mitigates Alzheimer-like pathology. Nat Med 14:681-687.

Townsend KP, Vendrame M, Ehrhart J, Faza B, Zeng J, Town T, Tan J (2004) $\mathrm{CD} 45$ isoform RB as a molecular target to oppose lipopolysaccharideinduced microglial activation in mice. Neurosci Lett 362:26-30.

Townsend KP, Town T, Mori T, Lue LF, Shytle D, Sanberg PR, Morgan D, Fernandez F, Flavell RA, Tan J (2005) CD40 signaling regulates innate and adaptive activation of microglia in response to amyloid beta-peptide. Eur J Immunol 35:901-910.

Walsh DM, Tseng BP, Rydel RE, Podlisny MB, Selkoe DJ (2000) The oli- gomerization of amyloid beta-protein begins intracellularly in cells derived from human brain. Biochemistry 39:10831-10839.

Walsh DM, Klyubin I, Shankar GM, Townsend M, Fadeeva JV, Betts V, Podlisny MB, Cleary JP, Ashe KH, Rowan MJ, Selkoe DJ (2005) The role of cell-derived oligomers of Abeta in Alzheimer's disease and avenues for therapeutic intervention. Biochem Soc Trans 33:1087-1090.

Watson D, Castaño E, Kokjohn TA, Kuo YM, Lyubchenko Y, Pinsky D, Connolly ES Jr, Esh C, Luehrs DC, Stine WB, Rowse LM, Emmerling MR, Roher AE (2005) Physicochemical characteristics of soluble oligomeric Abeta and their pathologic role in Alzheimer's disease. Neurol Res $27: 869-881$.

Wengenack TM, Whelan S, Curran GL, Duff KE, Poduslo JF (2000) Quantitative histological analysis of amyloid deposition in Alzheimer's double transgenic mouse brain. Neuroscience 101:939-944.

Wenk GL (2003) Neuropathologic changes in Alzheimer's disease. J Clin Psychiatry 64 [Suppl 9]:7-10.

Wertkin AM, Turner RS, Pleasure SJ, Golde TE, Younkin SG, Trojanowski JQ, Lee VM (1993) Human neurons derived from a teratocarcinoma cell line express solely the 695-amino acid amyloid precursor protein and produce intracellular beta-amyloid or A4 peptides. Proc Natl Acad Sci U S A 90:9513-9517.

West MJ, Slomianka L, Gundersen HJ (1991) Unbiased stereological estimation of the total number of neurons in the subdivisions of the rat hippocampus using the optical fractionator. Anat Rec 231:482-497.

Wilcock DM, Gordon MN, Ugen KE, Gottschall PE, DiCarlo G, Dickey C, Boyett KW, Jantzen PT, Connor KE, Melachrino J, Hardy J, Morgan D (2001) Number of Abeta inoculations in APP+PS1 transgenic mice influences antibody titers, microglial activation, and congophilic plaque levels. DNA Cell Biol 20:731-736.

Wild-Bode C, Yamazaki T, Capell A, Leimer U, Steiner H, Ihara Y, Haass C (1997) Intracellular generation and accumulation of amyloid betapeptide terminating at amino acid 42. J Biol Chem 272:16085-16088.

Wisniewski HM, Frackowiak J (1998) Commentary to "Differences between the pathogenesis of senile plaques and congophilic angiopathy in Alzheimer disease" [J Neuropathol Exp Neurol (1997) 56:751-761]. J Neuropathol Exp Neurol 57:96-98.

Wroblewski M, Hamann A (1997) CD45-mediated signals can trigger shedding of lymphocyte L-selectin. Int Immunol 9:555-562.

Wyss-Coray T (2006) Inflammation in Alzheimer disease: driving force, bystander or beneficial response? Nat Med 12:1005-1015.

Xu H, Sweeney D, Wang R, Thinakaran G, Lo AC, Sisodia SS, Greengard P, Gandy S (1997) Generation of Alzheimer beta-amyloid protein in the trans-Golgi network in the apparent absence of vesicle formation. Proc Natl Acad Sci U S A 94:3748-3752.

Zhu Y, Hou H, Nikolic WV, Ehrhart J, Rrapo E, Bickford P, Giunta B, Tan J (2008) CD45RB is a novel molecular therapeutic target to inhibit Abeta peptide-induced microglial MAPK activation. PLoS One 3:e2135. 